\title{
Nematicide activity of microfungi (Orbiliales, Orbiliaceae) after transit through gastrointenstinal tract of "Gallus gallus domesticus"
}

\author{
Atividade nematiciada de microfungos (“Orbiliales, Orbiliaceae”) após trânsito \\ gastrointestinal de Gallus gallus domesticus
}

\author{
SILVA, Manoel Eduardo da ${ }^{1 *}$; SILVEIRA, Wendeo Ferreira da $^{2}$; BRAGA, Fábio \\ Ribeiro $^{2,3}$; ARAÚJO, Jackson Victor de ${ }^{2}$
}

\footnotetext{
${ }^{1}$ Empresa de Pesquisa Agropecuária de Minas Gerais, Pitangui, Minas Gerais,Brasil.

${ }^{2}$ Universidade Federal de Viçosa, Departamento de Veterinária, Viçosa, Minas Gerais,Brasil.

${ }^{3}$ Universidade Vila Velha, Vila Velha, Espírito Santo,Brasil.

*Endereço para correspondência: manoelsilva@epamig.br
}

\section{SUMMARY}

Parasites are common in intensive or organics systems destined for chickens, which is more conducive to the emergence of gastrointestinal parasites, favored by direct contact with soil and other organisms. The growing demand for animal protein stimulates an expansion of production systems, increasing the stocking density. Outdoor poultry breeding systems (organic or not) that enable lower population density and higher animal welfare does not exclude these animals the presence of environmental pathogens. The control of gastrointestinal helminthosis in non-organic intensive and extensive systems is accomplished by administering anthelmintics with high cost and results unsatisfactory due to the misuse of drugs with consequent selection parasite strains resistant to chemical bases. This problem stimulate research into alternative control measures. Nematophagous fungi are used by its enzymatic action in controlled conditions and how environmental biocontrolers of larvae of gastrointestinal nematodes of livestock. This study evaluated the capacity of conidia/chlamydospores of nematophagous fungi as Duddingtonia flagrans (AC001 and CG722) and Monacrosporium thaumasium (NF34A) for cross the gastrointestinal tract of domestic chickens (Gallus gallus domesticus), and yours germination after traffic and predatory activity "in vitro" on larvae of
Panagrellus spp. Fungi conidia/chlamydospores was identified in feces of chickens at times of 6 , 12 and 24 hours after administration and spores viability was found after observing the germination, mycelial growth, followed by production of traps, capture and death of Panagrellus spp larvae in feces. Fungi Nematophagous are alternative control measures, efficient and innovative technology for the biological control of helminth parasites of chickens.

Keywords: biological control, Duddingtonia flagrans, nematophagous fungi, Monacrosporium thaumasium, poultry

\section{RESUMO}

Parasitas são comuns em sistemas intensivos avícolas ou orgânicos, mais propício para o surgimento de parasitas gastrointestinais, favorecido pelo contato direto dos animais com o solo e outros organismos. O aumento da demanda por proteína animal estimula a expansão dos sistemas de produção com aumento da densidade animal. Sistemas de criação livres (orgânicos ou não) com baixa densidade e alto padrão tecnológico não excluem estes animais do contato com patógenos ambientais. $\mathrm{O}$ controle das helmintoses gastrointestinais em sistemas extensivos ou intensivos não orgânicos é 
realizado pela administração de anti helmínticos com elevado custo e resultados insatisfatórios devido ao mau uso dos produtos com consequente seleção de cepas parasitárias resistentes às bases químicas. Este problema estimula a pesquisa de medidas alternativas de controle. Fungos nematófagos são utilizados por sua atividade enzimática em condições controladas e como biocontroladores de larvas de namatóides gastrointestinais em animais. Este estudo avaliou a capacidade de conídios/clamidósporos dos fungos nematófagos Duddingtonia flagrans (AC001 e CG722) e Monacrosporium thaumasium (NF34A) passar pelo trato gastrointestinal de galinhas domésticas (Gallus gallus domesticus), a germinação após passagem e atividade predatória "in vitro" sobre larvas de Panagrellus spp. Conídios/clamidósporos fúngicos foram identificados nas fezes das aves nos tempos 6 , 12 e 24 horas após administração e a viabilidade dos esporos foi contatada após germinação, crescimento micelial, seguido pela produção de armadilhas, captura e destruição de larvas de Panagrellus spp. nas fezes. Fungos nematófagos são medidas alternativas de controle, uma eficiente tecnologia e inovadora para o controle biológico de helmintos parasitas de aves.

Palavras-chave: avicultura, controle biológico, Duddingtonia flagrans, fungos nematófagos, Monacrosporium thaumasium

\section{INTRODUCTION}

The Brazilian production of chicken meat has increased considerably and the country is now the world's third largest producer and leader in exports (RODRIGUES et al., 2014). The growing demand for animal protein stimulates a rapid expansion of production systems and increasing the stocking density, favoring the multiplication and spread of pathogens. Outdoor poultry breeding systems that enable lower population density and higher animal welfare does not exclude these animals the presence of environmental pathogens (SOBRAL et al., 2010).
Parasites are common in intensive or organics systems of chickens, which is more conducive to the emergence of gastrointestinal parasites, favored by direct contact with soil and other organisms (RUFF, 1999; SHEIKH et al., 2015, VIEIRA et al., 2015). Helminths are responsible for economic losses due to decreased food intake, reduced growth and posture, leading to nutritional deficiencies that makes the birds susceptible to other infectious diseases and can lead to death (CARDOZO \& YAMAMURA, 2004; UHUO et al., 2013; HASSAN et al., 2015; THAPA et al., 2015).

The control of gastro-intestinal helminthosis in non-organic intensive and extensive systems is accomplished by administering anthelmintics with high cost and results unsatisfactory due to the misuse of drugs with consequent selection parasite strains resistant (THOMAZ-SOCCOL et al., 2004; AHMAD et al., 2013; SILVA et al., 2015). Contaminating the environment and serving as a source of contagion to other birds, generate residues in animal products (HERD, 1996; SHARMA et al., 2015).

The search for products contaminationfree chemical implies the no use of medication, either for prophylaxis or treatment of diseases. Nematophagous fungi are used by its enzymatic action in controlled conditions and as environmental biocontrolers of larvae of gastrointestinal nematodes of livestock (THAMSBORG et al., 1999; BRAGA \& ARAÚJO, 2014; HOSTE et al., 2015).

The basic principle for future biochemical experiments is to check the bioactivity of fungal structures after passage through the gastrointestinal tract (GIT) of the animal. This study evaluated the capacity of conidia/chlamydospores of $D$. flagrans 
(Dudd.) R.C. Cooke (strains AC001 and CG722) and M. thaumasium (Drechsler) de Hoog \& Oorschot (strain NF34A) through the gastrointestinal tract of domestic chickens (Gallus gallus domesticus), yours germination after the passage and predatory activity "in vitro" on larvae of Panagrellus spp.

\section{MATERIAL AND METHODS}

The experiment was conducted in the dependencies of the Laboratory of Parasitology of Department of Veterinary, Federal University of Viçosa (DVT/UFV) in Viçosa - MG.

Two isolates of D. flagrans (AC001 and CG722) and one of $M$. thaumasium (NF34A) belonging to mycology collection of the Parasitology Laboratory of DVT/UFV, kept in culture tubes AA2\% (Water Ágar 2\%) at $4^{\circ} \mathrm{C}$ in the dark were transferred in Petri dishes of $9.0 \mathrm{~cm}$ diameter containing CMA 2\% (Corn Meal Ágar $2 \%$ ) then incubated in an BOD (Biochemical Oxygen Demand) chamber at $25^{\circ} \mathrm{C}$ for 28 days. Ten $\mathrm{mL}$ of destilled water were added to the plate with the fungus grow, with the aid of a brush the fungal spores were removed, collected in a beaker and the volume completed to $10 \mathrm{~mL}$. After homogenization, five aliquots of $10 \mathrm{uL}$ of this solution were evaluated in a Neubauer chamber for quantification and identification of conidia/ chlamydospores according to the key proposed by Liu \& Zhang (1994) and Van Oorschot (1985). The average of these counts was extrapolated the average-number of reproductive structures in solution, after quantified were diluted in distilled water to a concentration of $6.4 \times 10^{4}$ spores per $\mathrm{mL}$ and stored at $4^{\circ} \mathrm{C}$.
Panagrellus spp maintained in culture in petri dishes containing oat flakes in Parasitology Laboratory DVT/UFV were washed 5 times with distilled water and centrifuge $500 \mathrm{G}$ for 5 minutes. After they were aliquoted 500 larvae. Eight chickens (G. Gallus domesticus), with approximately 6 months of age and average weight of $2.750 \mathrm{~kg}$ were kept in cages lined with plastic floor and divided into treatment groups, receiving commercial feed autoclaved and water "ad libitum".

The study was conducted in assay A and $\mathrm{B}$. The assay A was evaluated the ability of fungal structures (conidia/chlamydospores) passing through the TGI of chickens and germinated in Petri dishes containing $\mathrm{AA} 2 \%$. In the assay $\mathrm{B}$ was evaluated the feasibility and predatory activity of fungi after passage through the GIT of chickens. The ability of fungal structures passing through the chicken GIT was evaluated at different times over a period of 3 days. The eight chickens were divided in pairs to make four experimental groups (G1, G2, G3 and G4). Every seven days was administered individually to each bird as a single dose orally $1 \mathrm{~mL}$ of aqueous solution containing $6.4 \times 10^{4}$ spores of isolates CG722, AC001, NF34A and distilled water without the presence of fungal structures (control group), in Latin Square design (SAMPAIO, 2007). In times of $6,12,24,48$ and 72 hours after administration fungi, fecal samples were collected with the aid of plastic bags on the floor of the cages, and then cleaning was carried. Fecal samples were collected at different times, homogenized by treatment group and about 2 grams spread on Petri dishes of $9.0 \mathrm{~cm}$ diameter containing AA2\%. Approximately 500 larvae Panagrellus spp were added to plates and these put in a BOD chamber at $25^{\circ} \mathrm{C}$ for 12 days. 
Every day the plates were examined under optical microscopy to visualize the presence of fungal structures and/or mycelial growth as described by Liu \& Zhang (1994) and Van Oorschot (1985). At the end of this period the larvae not preyed was recovered by the Baermann technique.

The average number of larvae recovered, after logaritimic transformation ( $\log$ $\mathrm{x}+1$ ), was subjected to analysis of variance and compared by Tukey test at $5 \%$ significance with BioEstat software 5.3 (AYRES et al., 2003).

\section{RESULTS AND DISCUSSION}

The fungal structures (conidia/ chlamydospores) the isolates CG722, AC001 and NF34A was identified in feces at intervals of 6,12 and 24 hours after administration, confirming the ability to resist the passage through the GIT of G. gallus domesticus. The resistance of spores (conidia and chlamydospores) of fungal isolates
(AC001, CG722 and NF34A) to pass through GIT of G. gallus domesticus and its recovery in the feces, suggest possible use of these organisms as biological controllers of the helminths, since Faedo \& Waller (1996) and Herd (1996) describe the growing demand for healthy foods free of drug residues.

The fungal growth in the test "in vitro" (Assay B) with consequent production mycelial and traps, followed by capture and predation of Panagrellus spp larvae confirms the viability of fungal structures after passage through GIT of chickens (Figure 1) and its predatory activity, corroborating with Braga et al. (2012) that showed the crude extract of $P$. chlamydosporia (isolated $\mathrm{VC} 1$ and VC4) reduced 64.1 and $56.5 \%$, respectively, the number of eggs of $A$. galli, demonstrating that nematophagous fungi may be used as biological controllers, especially in agroecologic systems which seek to produce healthy food of high nutritional value and free of contaminants, preserving biodiversity in which it operates production system.

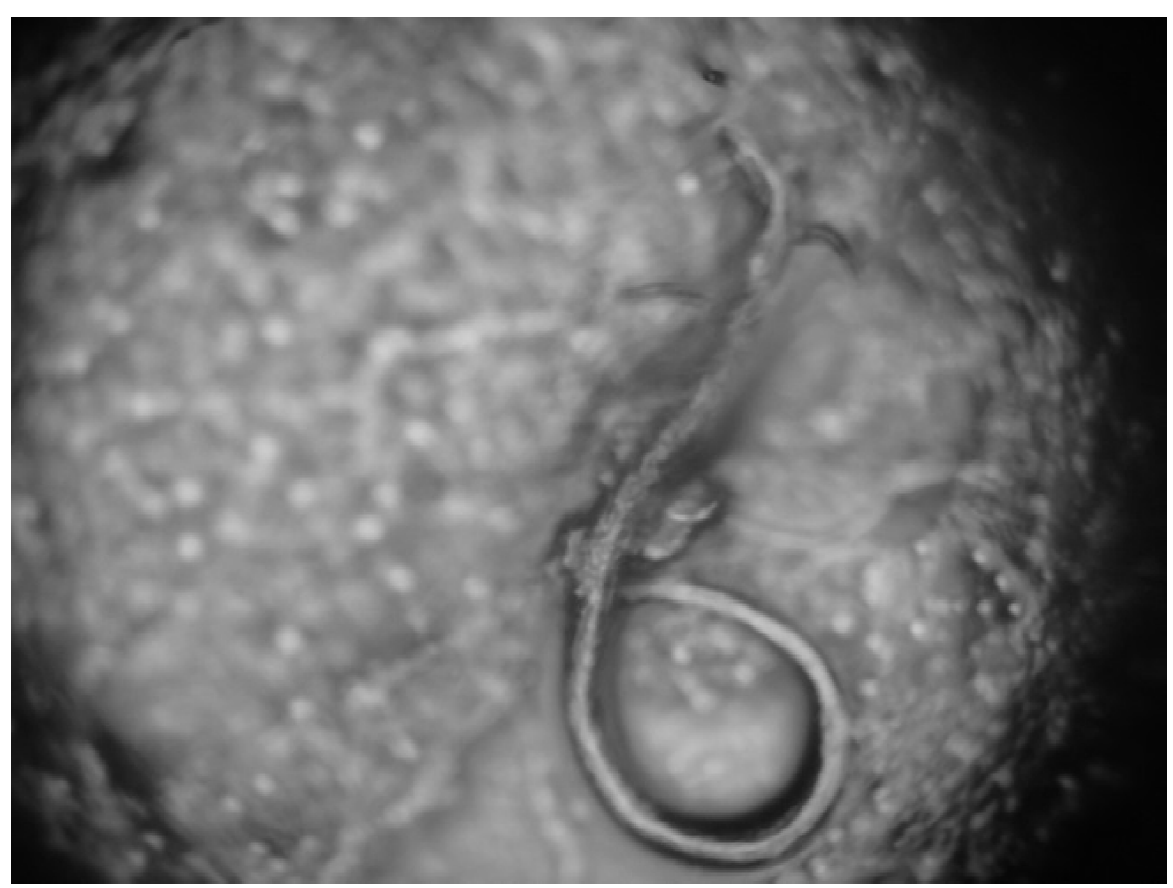


Figure 1. D. flagrans-traps (AC001) preying Panagrellus spp larvae in Petri dishes with AA2\% - 40x magnification

The best percentage of reduction Panagrellus spp was the time 6 hours after administration fungal. At this time, the isolated AC001, CG722 and NF34A had, respectively, a reduction of 70.57 $(p<0.05), 34.98$ and $65.89 \%$ of the number of Panagrellus spp larvae (Figure 2 and Table 1) agreeing to Braga et al. (2013) also demonstrated in the test "in vitro" that D. flagrans (AC001 and CG722) and $A$. cladodes (CG719) were efficient in preying $\mathrm{L}_{3}$ Libyostrongylus douglassii after seven days, reducing by 85.2\% (AC001), 81.2\% (CG722) and $89.2 \%$ (CG719) the average number of $\mathrm{L}_{3}$ recovered. Genier et al. (2015) demonstrated the enormous applicability of biological control by Pleurotus ostreatus (PLO06) and their proteases on larvae of Panagrellus spp with reduction of 65.6, 77.4 and $95.2 \%$ after 24, 48 and 72 hours, respectively.

Although most predatory activity has been observed in time six hours after administration for all fungal isolates, only the isolated AC001 showed a statistically significant difference $(\mathrm{p}<0.05)$ compared to control. Hiura et al. (2015) showed that
D. flagrans (AC001) and $P$. chlamydosporia (VC4) were effective in reducing the infectivity of eggs and tissue migration of Toxocara canis for chickens (G. gallus domesticus) after previous contact with them, reducing $87.1 \%$ (AC001) and $84.5 \%$ (VC4) the number of eggs recovered from liver, muscle, lung and intestine. Thapa et al. (2015) demonstrate on water agar that $P$. chlamydosporia Biotype 10 had reduced the viability of $A$. gall and $T$. caniseggs by $64-86 \%$ and $26-67 \%$, may be utilised as a biocontrol agent to reduce contamination of the environment, corroborating the idea of our work.

Once spores were visualized in the stool until the time 24 hours after its administration was not observed reduction in the number of larvae Panagrellus spp from the time 48 or 72 hours in the reduction test of larvae (Assay B) by any of the fungal isolates $(p<0.05) \quad($ Table 1). This observation provides biosecurity standard, reducing environmental flood by nematophagous fungi.

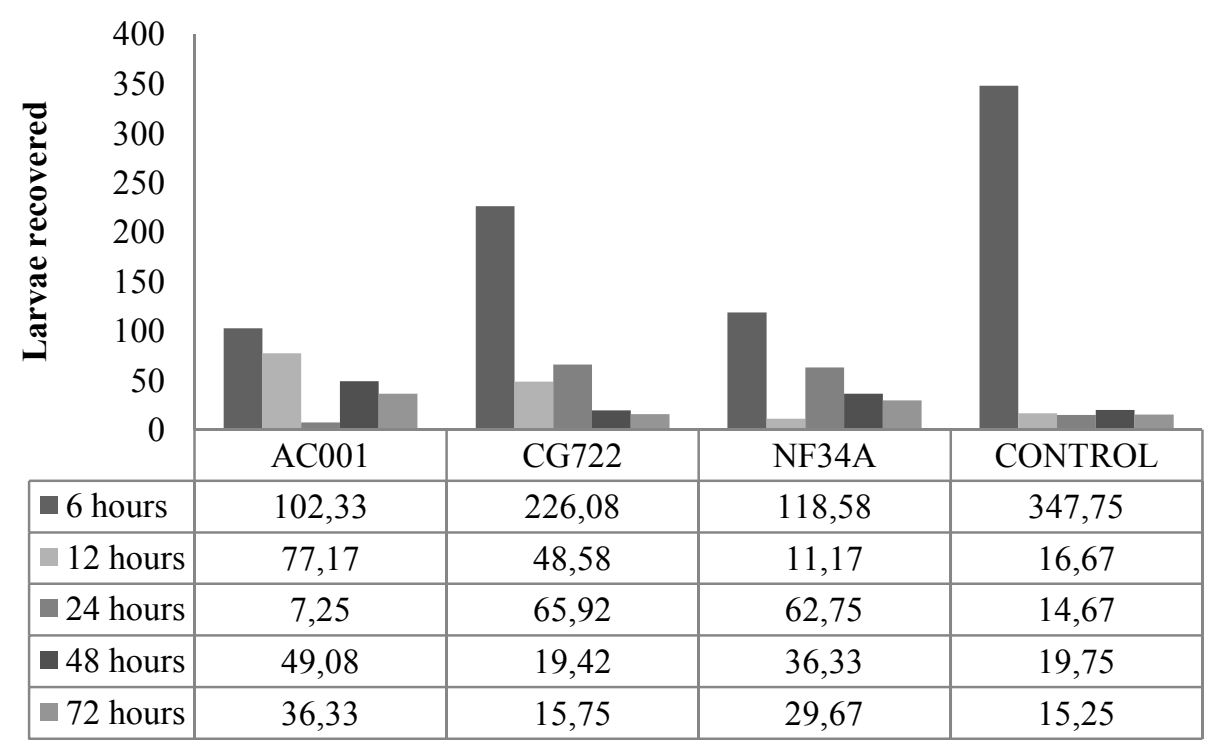


Figure 2. Destruction of Panagrellus spp larvae by D. flagrans (AC001 and CG722) and M. thaumasium (NF34A) after passage through the gastrointestinal tract of G. gallus domesticus

Table 1. Number average, standard deviation and \% reduction of Panagrellus spp larvae recovered to Baermann technique 12 days after interaction with $D$. flagrans (AC001 and CG722) and M. thaumasium (NF34A) in Petri dishes

\begin{tabular}{|c|c|c|c|c|c|}
\hline Time & Parameters & AC001 & CG722 & NF34A & CONTROL \\
\hline \multirow[t]{2}{*}{6 hours } & $\begin{array}{l}\text { Number average Standard } \\
\text { deviation }\end{array}$ & $\begin{array}{c}102,33 \\
( \pm 111,02)^{\mathrm{a}}\end{array}$ & $\begin{array}{c}226,08 \\
( \pm 297,85)^{\mathrm{ab}}\end{array}$ & $\begin{array}{c}118,58 \\
( \pm 91,21)^{\mathrm{ab}}\end{array}$ & $\begin{array}{c}347,75 \\
( \pm 290,82)^{b}\end{array}$ \\
\hline & $\%$ reduction & -70.57 & -34.98 & -65.89 & 0 \\
\hline \multirow[t]{2}{*}{12 hours } & $\begin{array}{l}\text { Number average Standard } \\
\text { deviation }\end{array}$ & $\begin{array}{c}77,17 \\
( \pm 96,35)^{\mathrm{a}}\end{array}$ & $\begin{array}{c}48,58 \\
( \pm 47,60)^{\mathrm{ab}}\end{array}$ & $\begin{array}{c}11,17 \\
( \pm 17,07)^{\mathrm{bb}}\end{array}$ & $\begin{array}{c}16,67 \\
( \pm 24,89)^{\mathrm{ab}}\end{array}$ \\
\hline & $\%$ reduction & +362.9 & +191.49 & -33.99 & 0 \\
\hline \multirow[t]{2}{*}{24 hours } & $\begin{array}{l}\text { Number average Standard } \\
\text { deviation }\end{array}$ & $\begin{array}{c}7,25 \\
( \pm 7,26)^{\mathrm{a}}\end{array}$ & $\begin{array}{c}65,92 \\
( \pm 81,00)^{\mathrm{a}}\end{array}$ & $\begin{array}{c}62,75 \\
( \pm 38,25)^{\mathrm{ab}}\end{array}$ & $\begin{array}{c}14,67 \\
( \pm 23,06)^{b b}\end{array}$ \\
\hline & $\%$ reduction & -50.56 & +349.43 & +327.83 & 0 \\
\hline \multirow[t]{2}{*}{48 hours } & $\begin{array}{l}\text { Number average Standard } \\
\text { deviation }\end{array}$ & $\begin{array}{c}49,08 \\
( \pm 38,31)^{\mathrm{a}}\end{array}$ & $\begin{array}{c}19,42 \\
( \pm 20,01)^{\mathrm{a}}\end{array}$ & $\begin{array}{c}36,33 \\
( \pm 35,70)^{\mathrm{a}}\end{array}$ & $\begin{array}{c}19,75 \\
( \pm 22,11)^{\mathrm{a}}\end{array}$ \\
\hline & $\%$ reduction & +148.5 & -1.6 & +83.94 & 0 \\
\hline \multirow{2}{*}{72 hours } & $\begin{array}{l}\text { Number average Standard } \\
\text { deviation }\end{array}$ & $\begin{array}{c}36,33 \\
( \pm 46,36)^{\mathrm{a}}\end{array}$ & $\begin{array}{c}15,75 \\
( \pm 15,08)^{\mathrm{a}}\end{array}$ & $\begin{array}{c}29,67 \\
( \pm 24,01)^{\mathrm{a}}\end{array}$ & $\begin{array}{c}15,25 \\
( \pm 13,84)^{\mathrm{a}}\end{array}$ \\
\hline & $\%$ reduction & +138.22 & +3.27 & +94.55 & 0 \\
\hline
\end{tabular}

Diferent small letters in lines mean statistically significant difference $(\mathrm{p}<0.05)$ - Tukey test.

Use of nematophagous fungi as biological controllers of helminth parasites of chickens is an efficient technology, innovative and low cost with possibility of use on all production systems, especially in conventional organic systems.

\section{ACKNOWLEDGMENTS}

This work was supported by the CNPq, Capes and Fapemig.

\section{REFERENCES}

AHMAD, J.; TANVEER, S.;

ZARGAR, B.A. In vitro anthelmintic activity of Mentha longifolia (L.) leaves against Ascaridia galli. Global

Veterinaria, v.11, p.112-117, 2013.

AYRES, M.; AYRES, J.R.M.; AYRES, D.L.; SANTOS, A.S. Aplicações estatísticas nas áreas de ciências biológicas. Brasília: Sociedade Civil Mamirauá, 2003.

BRAGA, F.R.; ARAÚJO, J.V. Nematophagous fungi for biological control of gastrointestinal nematodes in domestic animals. Applied Microbiology Biotechnology, v.98, p.71-82, 2014. 
BRAGA, F.R.; ARAÚJO, J.V.; TAVELA, A.O.; VILELA, V.L.R.; SOARES, F.E.F.; ARAUJO, J.M.; MAGALHÃES, L.Q.; SILVEIRA, W.F.; FEITOSA, T.F.; DANTAS, E.S.; ATAHYDE, A.C.R. (2013) First report of interaction of nematophagous fungi on Libyostrongylus douglassii (Nematoda: Trichostrongylidae).

Revista Brasileira de Parasitologia Veterinária, v.22, p.147-151, 2013.

BRAGA, F.R.; ARAÚJO, J.V.; ARAUJO, J.M.; FRASSY, L.N.; TAVELA, A.O.; SOARES, F.E.F.; CARVALHO, R.O.; QUEIROZ, L.M.; QUEIROZ, J.H. Pochonia chlamydosporia fungal activity in a solid medium and its crude extract against eggs of Ascaridia galli. Journal of Helminthology, v.86, p.348-352, 2012 .

CARDOSO, S.P.; YAMAMURA, M.H. Parasitas em produção de frangos nos sistema de criação tipo colonial/caipira no Brasil. Semina: Ciências Agrárias, v.25, p.63-74, 2004.

GENIER, H.L.A.; SOARES, F.E.F.; QUEIROZ, J.H.; GOUVEIA, A.S.; ARAÚJO, J.V.; BRAGA, F.R.; PINHEIRO, I.R.; KASUYA, M.C.M. Activity of the fungus Pleurotus ostreatus and of its proteases on Panagrellus sp. larvae. African Journal of Biotechnology, v.14, p.1496-1503, 2015.

GRANDO, T.H.; DE SÁ, M.F.; BALDISSERA, M.D.; OLIVEIRA, C.B.; DE SOUZA, M.E.; RAFFIN, R.P.; SANTOS, R.C.; DOMINGUES, R.; MINHO, A.P.; LEAL, M.L.; MONTEIRO, S.G. (2015) In vitro activity of essential oils of free and nanostructured Melaleuca alternifolia and of terpinen-4-ol on eggs and larvae of Haemonchus contortus. Journal of

Helminthology, v.22, p.1-6, 2015.

HASSAN, N.N.R.N.; AWANG, A.; RAHMAN, M.S. Parasitic burden and its relation with the body weight of free range chicken in Oil Palm Dominated Sandakan District of Malaysian Borneo. International Journal of Livestock Research, v.5, n.9, p.10-20, 2015.

HERD, R. Impactos ambientais associados aos compostos endectocidas. In: PADILHA, T. (Ed.). Controle dos nematódeos gastrintestinais em ruminantes. Coronel Pacheco: EMBRAPA-CNPGL, 1996. p.95-111.

HIURA, E.; LOPES, A.C.G.; PAZ, J.S.; GAVA, M.G.; FLECHER, M.C.; COLARES, M.; SOARES, F.E.F.; FONSECA, L.A.; LACERDA, T.; ARAÚJO, J.V.; BRAGA, F.R. Fungi predatory activity on embryonated Toxocara canis eggs inoculated in domestic chickens (Gallus gallus domesticus) and destruction of second stage larvae. Parasitology Research, v.114, p.3301-3308, 2015.

HOSTE, H.; TORRES-ACOSTA, J.F.J.; SANDOVAL-CASTRO, C.A.; MUELLER-HARVEY, I.; SOTIRAKI, S.; LOUVANDINI, H.; THAMSBORG, S.M.; TERRILL, T.H. Tannin containing legumes as a model for nutraceuticals against digestive parasites in livestock. Veterinary Parasitology, v.212, n.1-2, p.5-17, 2015.

LIU, X.Z.; ZHANG, K.Q. Nematodetrapping species of Monacrosporium with special reference to two new species. Mycology Research, v.98, p.862-868, 1994.

RODRIGUES, W.O.P.; GARCIA, R.G.; NÄÄS, I.A.; ROSA, C.O.da; 
CALDARELLI, C.E. (2014) Evolução da avicultura de corte no Brasil. Centro Científico Conhecer, v.10, p.16661684, 2014.

RUFF, M.D. Important parasites in poultry production systems. Veterinary Parasitology, v.84, p.337-347, 1999.

SAMPAIO, I.B.M. Estatística aplicada à experimentação animal. Belo Horizonte: Fundação de Estudo e Pesquisa em Medicina Veterinária e Zootecnia, 2007.

SHARMA, N.; SINGH, V.; SHYMA, K.P. Role of parasitic vaccines in integrated control of parasitic diseases in livestock. Veterinary World, v.8, p.590-598, 2015.

SHEIKH, B.A.; SOFI, T.A.; AHMAD, F. Prevalence of helminth parasites in Gallus domesticus from Gurez valley. Agricultural Advances, v.4, n.11, p.129-137, 2015.

SILVA, M.E.; BRAGA, F.R.; MENDOZA DE GIVES, P.; MILLÁNOROZCO, J.; URIOSTEGUI, M.A.M.; MARCELINO, L.A.; SOARES, F.A.F.; ARAÚJO, A.L.; VARGAS, T.S.; AGUIAR, A.R.; SENNA, T.; RODRIGUES, M.G.; FROES, F.V.; ARAÚJO, J.V. Fungal antagonism assessment of predatory species and producers metabolites and their effectiveness on Haemonchus contortus infective larvae. Biomed Research International, p.1-6, 2015.

SOARES, F.E.F.; BRAGA, F.R.; ARAÚJO, J.V.; LIMA, W.S.; MOZER, L.R.; QUEIRÓZ, J.H. (2012) In vitro activity of a serine protease from Monacrosporium thaumasium fungus against first-stage larvae of Angiostrongylus vasorum.
Parasitology Research, v.110, p.24232427, 2012.

SOBRAL, F.E.S.; BRANDÃO, P.A.; ATHAYDE, A.C.R. Utilização de fitoterápicos no tratamento de parasitoses em galinhas caipira criadas em sistema semiextensivo.

Agropecuária Científica no SemiÁrido, v.6, p.1-6, 2010.

THAMSBORG, S.M.; ROEPSTORFF, A.; LARSEN, M. (1999) Integrated and biological control of parasites in organic and conventional production systems.

Veterinary Parasitology, v.84, n.3-4, 1999.

THAPA, S.; HINRICHSEN, L.K.; BRENNINKMEYER, C.; GUNNARSSON, S.; HEERKENS, J.L.T.; VERWER, C.; NIEBUHR, K.; WILLETT, A.; GRILI, G.; THAMSBORG, S.M.; SORENSEN, J.T.; MEJER, H. (2015) Prevalence and magnitude of helminth infections in organic laying hens (Gallus gallus domesticus) across Europe. Veterinary Parasitology, v.214, n.1-2, p.118-24, 2015.

THAPA, S.; MEYLING, N.V.; KATAKAM, K.K.; THAMSBORG, S.M.; MEJER, H. A method to evaluate relative ovicidal effects of soil microfungi on thick-shelled eggs of animal-parasitic nematodes. Biocontrol Science Technology, v.25, n.7, p.756767, 2015.

THOMAZ-SOCCOL, V.; SOUZA, F.P.; SOTOMAIOR, C.; CASTRO, E.A.; MILCZEWSKI, V.; MOCELIN, G.; SILVA, M.C.P. Resistance of gastrointestinal nematodes to anthelmintics in sheep (Ovis aries).

Brazilian Archives Biology and Technology, v.47, p.41-47, 2004. 
UHUO, A.C.; OKAFOR, F.C.;

ODIKAMNORO, O.O;, ONWE, C.S.;

ABARIKE, M.C.; ELOM, J.N.

Common gastrointestinal parasites of

local chicken (Gallus domesticus)

slaughtered in some selected eatery

centres in Abakaliki, Ebonyi State:

Implication for meat quality.

International Journal of Development

and Sustainability, v.2, p.1416-1422,

2013.

VAN OORSCHOT, C.A.N. Taxonomy of the Dactylaria complex. A review of Arthrobotrys and allied genera.

Studies in Mycology, v.26, p.61, 1985.

VIEIRA, F.E.G.; YAMAMURA, M.H.;

FREIRE, R.L.; HEADLEY, S.A. The

effects of managerial systems on

helminth infection in free range

chickens from northern Paraná, Brazil.

Semina: Ciências Agrárias, v.36, n.6, p.4311, 2015. Supl. 2.

WALLER, P.; FAEDO, M. The prospects for biological control of the free-living stages of nematodes parasites of livestock. International Journal for Parasitology, v.26, p.915925, 1996.

Data de recebimento: $31 / 05 / 2016$

Data de aprovação: 25/11/2016 